\title{
Research on Differences between the Crime of Corruption and the Crime of Unauthorized Partition of State-owned Assets
}

\author{
Li Lei \\ Law School, Huazhong University of Science and Technology, Wuhan, Hubei, China, 430074 \\ 346591653@163.com
}

Keywords: Crime of corruption, Crime of unauthorized partition state-owned assets, State-owned assets

\begin{abstract}
The crime of unauthorized partition state-owned assets is a new crime in 1997 Criminal Law, which is born out from the Crime of Corruption. They are similar in object of crime, objective aspect of crime and subject of crime. This paper expounds the differences between the two crimes on the criminal subjects, criminal purposes, behavior patterns, damage degrees and criminal amounts in order to provide references to distinguish them in judicial practices.
\end{abstract}

\section{Introduction}

In judicial practices, we can see the phenomenon that some individuals or small groups in state-owned companies violate the laws to take the bonuses, royalties and other state assets. The crime of corruption and the crime of unauthorized partition of state-owned assets in economic crimes are often difficult to distinguish. So how to correctly distinguish, criminal responsibility and punishment to adapt, is of great significance. Crime of corruption is that national staff and by state organs, state-owned companies, enterprises, institutions, people's organizations entrusted management and personnel of state-owned property management, taking advantage of his position, embezzle, steal, cheat or to other means of illegal possession of public property. The crime of unauthorized partition of state-owned assets is refers to the state organs, state-owned companies, enterprises, institutions, people's organizations, in violation of the relevant provisions of the state, in the name of the unit will be collective unauthorized partition of state-owned assets to individuals, the amount of larger behavior. In particular, both in the objective aspects of the implementation of the common corruption of state-owned assets or assets, and the object of joint corruption can also be state-owned assets, the most easily confused in practice. Corruption and bribery crime is referred to a kind of crime, refers to the national staff of the implementation of the corruption, bribery, misappropriation of public funds, corruption and dereliction of duty, endangering the integrity of official acts, a breach of the normal activities of the state organs, and other individuals or organizations in the implementation of and national staff corruption and crimes of dereliction of duty behavior has relevance or to the crime. As the object of the crime of corruption and bribery, it has the same characteristics as the violation of the country's system of government. The crime of unauthorized partition of state-owned assets is derived from the crime of corruption. The structural arrangement of this kind of legislation reflects that there are some similarities between the two objects.

\section{Differences between the two Crimes}

\section{A: Differences between Criminal Subjects}

The subject of the crime of corruption is the natural person. However, the subject of crime for the crime of unauthorized partition of state-owned assets can only be the state-owned units. 
Although criminal law stipulates point out that "directly responsible persons in charge and other persons liable", but this does not mean that natural person can become the subject of unit crime. In the unit crime, the natural person is the responsibility of the unit crime, but not the identity of the subject of crime to bear criminal responsibility. Natural person in the unit crime should bear criminal responsibility, depending on this unit subject of crime in law is able to be convicted of murder, so natural person in the unit crime bear criminal responsibility in the role of attachment never out of units were judged to be guilty of premise alone to bear the criminal responsibility. National staff refers to itself does not have the status of national staff, but due to the special position of himself with the identity of the national staff to become the national staff, such as by state organs and other units assigned to other units engaged in public service personnel, subject to state organs and other units entrusted management and operation personnel of state-owned property. The natural person in the unit crime, and the only unit together to become the main unit and not be punished, constitute the subject of crime. Corruption crime is a natural person crime, its main body is the national staff, is a kind of special natural person crime. According to the current ninety-third article of "Criminal Law" and related judicial interpretation of the provisions, the main body of the crime of corruption can be divided into national staff and quasi national staff. National staff is the person who has the identity of the state, and is engaged in official duties at all levels of state organs.

\section{B: Differences between Criminal Purposes}

The crime of corruption is the behavior that the state personnel take advantage of his position to occupy the public property illegally. From the point of view of the subjective aspect of the crime, the behavior is illegal possession of public property deliberately; from the point of view of objective behavior is behavior person take corruption, stealing and cheating and other means of illegal possession of public property. Individuals guilty of corruption, has the right to decide who use his authority to facilitate illegal to seek personal gain, common crime of corruption, or is a few has the right to decide who collude with the decision illegal possession of public property, or is a has the right to decide who and other minority person or with public property management functions of accounting personnel in collusion, to carve up the common public property, are completely selfish. The subjective malignant degree is deeper. The integrity of the national staff's duty requires that the state personnel should abide by the party discipline and state laws and regulations, and maintain their own integrity. The implementation of the crime of corruption is completely out of the requirements. Its consequences not only undermine the image of the national staff itself, but also a serious violation of the integrity of the state. In a word, no matter how personal corruption or common corruption, promote person's behavior implementation of the purpose and motive of crime is for their plunder property, to line their own pockets, with full of selfishness, its social harmfulness is very large. The crime of unauthorized partition of state-owned assets crime purpose and motivation is altruistic, actor's subjective malignant is not deep. On the contrary, the behavior will is considered to be the fair use of the company of state-owned assets.

\section{C: Differences between Behavior Patterns}

The behavior pattern of the crime of corruption is illegal possession of public property. But the behavior pattern of the crime of unauthorized partition of state-owned assets is dividing "small treasuries" money. The whole will of the unit penetrates the process from the set-up of "small exchequer" to dividing it. If there is no unit will reflect, just behavior of individual decision, then it does not constitute of unauthorized partition of state-owned assets, and can only be identified as corruption. Theft type of illegal possession is the behavior of the person who takes the secret way to their legitimate handling, management of public property. In this way to obtain ownership of public property should be in before it is placed in the behavior of people and other common management, 
if just behavior were administered separately, then it is very likely constitute corruption and theft. Theft of illegal possession requires the behavior of people secretly possession of public and private property. The behavior of the corruption crime refers to in addition to the behavior of people, the other members of the unit or units are not informed of the. And the crime of unauthorized partition of state-owned assets of the "secret" is for the state-owned assets supervision and administration institution, the partition behavior in the interior of their flats in the open or semi open state, members of the unit this is informed. Illegal possession of illegal possession refers to the behavior of people taking advantage of his position, by concealing the truth or to take the method of fictional facts, illegal possession of public property. Illegally obtained by this way the public property should be lawful management of others but have the right to handle. Practice fraud means generally include unauthorized fill in the blank documents, false impersonator various public funds, correction of reimbursement, increasing amount of reimbursement to illegal possession of public property. Crime of unauthorized partition of state-owned assets can be divided by all sorts of excuses, such as dark money or subsidy. The main difference is the crime behaviors represent the will of the individual or not.

\section{D: Differences between of Damage Degrees}

The crime of unauthorized partition of state-owned assets is the man who has the right to decide whether to use his authority to facilitate illegal as we seek interests, therefore, the subjective malignant degree is relatively light; the characteristics of common crime of corruption is has the right to decide to use his authority to facilitate for a handful of people to seek private gain, thus showing deep subjective malignancy. In the crime of unauthorized partition of state-owned assets has the right to decide who may is a person, may also for several people, but compared to the other in unauthorized partition of state-owned assets is to be a small number of people. Due to the basic characteristics of this crime, is a few people, most of them illegal interests: Joint corruption crime in either is a few have the right to determine collusion common corruption of public property: either one or several has the right to decide with very few public informed or gymnastics do accountants collude. In addition, from the judicial level analysis, if the behavior of collective of dividing up state-owned assets on to the crime of corruption, all dividing the amount identified as above has the right. Both with the objective facts do not fully comply with, theory also and corruption should to "an individual who embezzles" as the basis of conviction and sentencing of the spirit of the legislation contrary, practice is very easy to create a heavy sentencing results, which lead to a miscarriage of justice. If the share of the person who has the right to decide the individual is identified as "the amount of personal corruption", then there is no need to give the necessary legal evaluation of the amount.

\section{E: Differences between of Criminal Amount}

The starting point of the crime of unauthorized partition of state-owned assets which should be prosecuted for criminal responsibility is about 100 thousand Yuan. There is the gap problem between the personal income and the unauthorized partition of state-owned assets. In judicial practice, this is a common interesting to ask, distinguish the crime of unauthorized partition of state-owned assets and joint corruption crime is another difficulty. In essence, it is the seek illegal interests for a minority of people, for fear of the law on the punishment, so dividing collective as an excuse, for yourself or a few people reap greater benefits and other employees ten points generally. Such as in the process of dividing unit directly negative expensive executives share several hundred thousand dollars, and other employees only share a few thousand dollars or less. Due to the crime of unauthorized partition of state-owned assets crime and corruption in filing standards, legal punishment differ a lot, the crime of corruption filing standards to considerably lower than that of 
the crime of unauthorized partition of state-owned assets, and legal punishment and heavy on the crime of unauthorized partition of state-owned assets, bear the scope of subject of criminal responsibility is different, so often some criminals by means of North attempt to evade or reduce the legal sanctions. The crime should be recognized depending on the behavior and the amount. According to the objective behavior performance combined with the subjective psychology of the criminals is canvass. If before dividing, the supervisor decides the amount depending on the personnel level, length of service, administrative rank or service level, it should also be judged as the crime of unauthorized partition of state-owned assets.

\section{Conclusion}

To distinguish the crime of corruption and the crime of unauthorized partition of state-owned assets is a complex process. In spite of this, there are also some differences between the two crimes. This article makes a comprehensive expatiation on the distinctions between the two crimes. To distinguish the corruption crime and the crime of unauthorized partition of state-owned assets will eventually be based on the continuous improvement of the "Criminal Law" and other relevant laws in judicial practices. We always believe that, with the continuous improvement of the legal system, the distinctions between the crime and the crime will be clearer in judicial practices.

\section{References}

[1] Yu Pin, How to Distinguish the Crime of Corruption and the Crime of Unauthorized partition of state-owned assets - The Case of a Certain Mr. Chen and so on, Citizen and Law, 2015 (7): 52-53.

[2] Xiao Taohong, Research on Difference between the Crime of Corruption and the Crime of Unauthorized Partition of State-owned Assets, D., Central South University, 2013.

[3] Yin Mingcan, Wang Mingkun, Review on Judicial Practice of the Crime of Dividing up State-Owned Assets, J., Journal of Sichuan Police College, 2010, 22(4): 37-46.

[4] Ouyang Guanghui, Research on the State-owned Assets Management of Administrative Institutions from the Perspective of Modern Finance, J., Public Finance Research Journal, 2015 (4): 65-70. 